Millatī, Journal of Islamic Studies and Humanities Vol. 4, No. 1, Juni 2019: p. 87-98. DOI: 10.18326/mlt.v4i1. 87-98 p-ISSN : 2541-3627; e-ISSN 2540-9964

Website: http://millati.iainsalatiga.ac.id/index.php/millati/index

\title{
Tolak Bala: A Relation Between Islam and Tradition
}

\author{
Syarifah Sajila Apjan \\ LAIN Pontianak, Indonesia \\ Syarifah.sajila19@gmail.com
}

\begin{abstract}
Islam and tradition are two different sides, they are debated when they are related. The topic has some similarities to the reality of some of today's society in addressing the differences of disputes and debates. This article is a research that aims to provide views and knowledge to public by researching the relations of Islam and traditions in the coastal areas of Dabong community, Kubu Subdistrict, District of Kubu Raya, West Kalimantan. Terminology of Islam and traditions which is not interconnected, can realize relationships and local wisdom. The research method used is qualitative research with the technique of data collection through interview. The subject of this research is the coastal community of Dabong, Kubu District, Regency of Kubu Raya, West Kalimantan. The results show that (1) The public understand that not all traditions are wrong even have Islamic values, and (2) Open the public's view that the difference is not an arena of debate, but a material to strengthen togetherness. The relationship between Islam and tradition can also open the public's view of peace, harmony, prosperity, so that can be concluded as a connecter of the nation.
\end{abstract}

Keywords: Relation, Islam, Tradition, Nation's Connecter

\begin{abstract}
Abstrak
Islam dan tradisi adalah dua sisi yang berbeda, mereka diperdebatkan ketika mereka terkait. Topik tersebut memiliki beberapa kesamaan dengan realitas beberapa masyarakat saat ini dalam mengatasi perbedaan sengketa dan perdebatan. Artikel ini adalah penelitian yang bertujuan untuk memberikan pandangan dan pengetahuan kepada publik dengan meneliti hubungan Islam dan tradisi di wilayah pesisir komunitas Dabong, Kecamatan Kubu, Kabupaten Kubu Raya, Kalimantan Barat. Terminologi Islam dan tradisi yang tidak saling berhubungan, dapat mewujudkan hubungan dan kearifan lokal. Metode penelitian yang digunakan adalah penelitian kualitatif dengan teknik pengumpulan data melalui wawancara. Subjek penelitian ini adalah masyarakat pesisir Dabong, Kecamatan Kubu, Kabupaten Kubu Raya, Kalimantan Barat. Hasil penelitian menunjukkan bahwa (1) publik memahami bahwa tidak semua tradisi salah bahkan memiliki nilai-nilai Islam, dan (2) Membuka pandangan publik bahwa perbedaan bukanlah arena perdebatan, tetapi bahan untuk memperkuat kebersamaan. Hubungan antara Islam dan tradisi juga dapat membuka pandangan publik tentang perdamaian, harmoni, kemakmuran, sehingga dapat disimpulkan sebagai penghubung bangsa.
\end{abstract}

Kata kunci: Relasi, Islam, Tradisi, Penghubung Bangsa 


\section{INTRODUCTION}

Born from two sides which are not related to each other, Islam and tradition have different positions. When we hear the relation between Islam and tradition, we will think about the relation between the two. This term is very attractive, because if we discuss about it, it will never be finished and even create two opinions, compatible and incompatible, even they may be contradictory.

Pater Jan Bakker said in his book entitled "Philosophy of Culture" that there is no relationship between religion and culture. According to him, religion is a spiritual belief of life, and culture is humans' creation. On the other hand, M. Natsir said that the source of culture is Islam; the main power that develops the culture is Islam. It should be called the culture with Islamic culture. (M. Natsir, 1988: 46). ${ }^{1}$ The controversy happening between Islam and local culture can be viewed from the arguments stated by two figures above. Research on Islam and local culture is important to discuss because both Islam and local culture cannot be separated.

The big problems in the world, especially in Indonesia that are happening now are injustice, corruption, crime, murder, dispute among communities, even war between communities and government can be learnt from the relation between Islam and tradition of tolak bala in Dabong village.

In addition, relation between Islam and tradition can be used as a teacher by big problem in Indonesia, because this relationship also contains a diversity of values that can strengthen the relationship and brotherhood among Indonesians. The meaning of diversity here is "unity in diversity." The value of relationship between Islam and tradition is the most expensive one and cannot be bought or sold. It can create a peaceful life of nation.

This article will explain about the results of research conducted in Dabong village, Kubu Raya Regency, Province of West Kalimantan Indonesia, which is one of the largest archipelagic countries in the world. This article discusses about the issues of: (1) tolak bala; local traditions of Dabong community, (2) tolak bala; rituals and interpretations of meanings, (3) Islam and tradition in theoretical perspectives, (4) Islam and tradition in a historical perspective, (5) relation between Islamic and tradition as nation connector (Islam and tradition in the Indonesian context, Islam and tradition in local context (Dabong)), (6) connector values of nation in relations between Islam and tradition of tolak bala.

\section{METHOD}

The method used in this research is qualitative method that has a natural way of conducting research with a subjective approach. Ibrahim said in his book of Qualitative Research Method "When discussed from a qualitative research paradigm, research methods are

${ }^{1}$ M. Natsir in his book of Islamic culture in historical perspective stated that the source of culture is Islam viewed from historical perspective. 
perspectives, beliefs, assumptions, concepts, propositions or perceptions regarding natural research, with a subjective approach, interpretive and contextual judgment." ${ }^{2}$

Natural way of conducting research is a research carried out directly, without referring to result of research from others. Natural way here means that the data obtained is the result of research conducted directly. While the subjective approach means collecting data by approaching the subject or person practicing tradition. It was conducted through direct interviews with the community in Dabong village.

The technical collecting data used in this research is interview. The writer conducted interview with the community of Dabong village who practice the tradition of tolak bala annually. Interview is the only way to collect the data in this study since the tradition of tolak bala is not carried out every time.

\section{A Local Tradition of Dabong Community}

Dabong is a small village at the end of Khatulistiwa city, Kubu District, Kubu Raya Regency, West Kalimantan Province, Indonesia, which is the largest archipelagic country in the world. Dabong is a small village occupied by a few people. Many migrants come to this village. However, Dabong village is rich of religious and cultural values.

The majority of Dabong village is Muslim because the urban village head in the past was Muslim. The people of this village didn't have strong religious knowledge, in other where their knowledge of religion was very limited. ${ }^{3}$ Therefore, the community of Dabong village still has a strong tradition and is maintained by some people even though the majority of their religion is Islam.

Tolak bala is one of the traditions carried out by the society of Dabong once a year. The majority of Dabong community said that the tradition of tolak bala was carried out in several steps: (1) praying for the village, (2) eating rice wrapped with coconut leaf and all the various dishes, (3) feeding the sea with boats loading food such as ketupat, cakes, tasteless flour and yellow rice and feeding the village by preparing offerings in the form of three types of rice, namely red, yellow and blue rice. ${ }^{4}$

In village of Dabong, this tradition is not prohibited because it is addressed to Allah the almighty to save the village. However, there is a controversy in tradition of tolak bala, there were some activities regarded wrong, namely feeding sea and village in certain places.

Some people believe that feeding the sea and village can save their villages from all calamities. However, for those who understand Islamic law, they do not do the tradition, because according to Islamic teaching it is forbidden. So, the people of Dabong who do not believe in the implementation of tradition such as feeding the sea and village, they just

\footnotetext{
${ }^{2}$ Ibrahim, 2015. Qualitative Research Method. Bandung : ALFABETA,cv. p. 10

${ }^{3}$ Interview with Ismail, 73 years old, one of informants who lives in Dabong village for a long time

${ }^{4}$ Interview with Suriani and Latif, 37 years old, both are the residents of Dabong village.
} 
take just pray and eat. There is no conflict among the people of Dabong village tough they have different perspective.

\section{Ritual and Interpretation of Meaning}

Anthropological studies relate rituals with feeding the sea and village as worship to God and magical objects. The ritual aims to demonstrate the interrelation of human life with religion. Conceptually, this is like what Max Gluckman said: "Ritual, that is to say, is associated with nations that its performance in some mysterious way, by process out of sensory control, affects the well-being of the participants: it is believed to protect them or in other ways achieve their well-being."

Basically, the tradition of tolak bala practiced by Dabong society such as ritual of feeding the sea and village was an effort of Dabong community to obtain protection from their Lord. One of those can be seen from the stages of implementing tolak bala ritual that there are Islamic values in tradition. For example, when implementing tradition of tolak bala, they opened it with saying basmalah then filled with prayers and closed with saying hamdalah. From the elaboration above, there is a relation between Islam and local traditions.

\section{Islam and Tradition in Theoretical Perspective}

Islam simply means the religion brought by Prophet Muhammad (peace be upon him) as the Messenger of Allah in the form of His word which teaches the happiness in the world and hereafter. Islam is a universal religion. It is as a way of life applied to all mankind in all places. This is universal Islam which can unite many people from different race, language, culture and geographical location. ${ }^{6}$

Umar bin Khattab interpreted Islam as a religion revealed by Allah to Prophet Muhammad. It includes the teaching of sharia and morality. From this opinion, that Islam is a form of faith, namely trust in Allah SWT. And the form of Islam itself is Prophet Muhammad who has noble moral. Allah SWT sent Prophet Muhammad to deliver His revelation and expression in the form of Quran.

Qur'an is a guide for Muslims. Islam is the theological foundation chosen and believed to be the most perfect religion, applied universally (rahmatan lil'alamin). Rahmatan lil'alamin means that Islam is the religion that brings mercy and prosperity for the entire universe, humans, animals, plants and spirit. As Allah SWT said in QS. Al-Anbiyaa' verse 107.

${ }^{5}$ Gluckman, Max (1966) Essay on The Ritual of sosial Relations, Manchester University Press, 1966. p. 32 in Saiful A.M dan Yuda S, 2015, Teori Kebudayaan Interaksi lokal dengan Wisata Regionaldan Global, PenerbitPerdana Mitra Handalan, medan. p. 62

${ }^{6}$ Mahmoud M. Ayoub, 2004. ISLAM between faith and ritualpractice. AK GROUP. Yogyakarta. p. 208

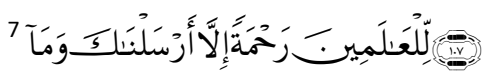


From the definitions above, it can be concluded that Islam is the religion which is rahmatan lil'alamin revealed by Allah SWT for the entire universe, humans, animals, plants and spirit, and the Messenger of Allāh chosen by Him to deliver Quran to guide people.

The word "tradition" according to Wikipedia derives from Latin "traditio" which means "forwarded" or "habit." In simplest definition, tradition is something that has been done for a long time and is part of community life which is usually from a country, culture, time, or the same religion. The most basic thing about tradition is the information that is forwarded from generation to generation both written and spoken.

Custom is a form of moral and the way humans think that has been manifested and practiced for long time that it is considered as tradition. According to Norazit Selat (1989), cited by Dedy Asfar (2007), tradition is a custom or law. ${ }^{8}$ This concept is known that tradition begins from a habit practiced continuously and feeling afraid when leaving it, because it contains custom or law.

From the explanation above, it can be concluded that tradition is a habit that originates from feeling of fear and anxiety, which lasts for generation to generation. When viewed from the tradition of tolak bala, feeling of fear and anxiety can be overcome by providing offerings. The tradition is maintained from the past until now, in other word, it has been passed down from generation to generation, and those who believe it are afraid to stop it, because it has custom or law. Tradition is part of culture, which has broad meaning.

\section{Islam and Tradition in Historical Perspective}

If viewed from historical perspective externally, Islam and tradition have related one another because the source of culture is Islam. M. Natsir said that the source of culture is Islam. The main power to develop culture is Islam. It should be called the culture with Islamic values or Islamic culture (M. Natsir, 1988: 46). ${ }^{9}$ Taken from a history in Quran, one of the verses that explain about it is Surah Al-Mujadalah: $11 .^{10}$

Above verse means that Islam is a religion that commands its people to think and seek for knowledge. In this verse we can draw conclusion that Islam is a source of culture. It is concrete that tradition which is part of culture cannot be separated from Islam, because the presence of culture is the process of thinking, and it is explained in Quran. M. Natsir in his book "Islamic Culture in a Historical Perspective" expressed the opinion of

\footnotetext{
${ }^{8}$ Hermansyah, et al. 2007. Islamic Dayak in West Kalimantan. Pontianak : STAIN Pontianak Press (Anggota IKAPI). p. 185

${ }^{9} \mathrm{M}$. Natsir in his book of Islamic culture in historical perspective stated that the source of culture is Islam viewed from historical perspective.
}

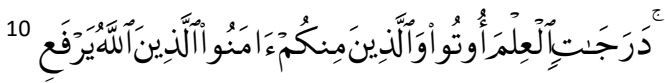


Prof. H.A.R. Gibb ${ }^{11}$ "Islam is indeed much more than a system of theology; it is a complete civilization". Islam is actually more than one religious system; Islam is a complete culture.

However, if viewed internally from a historical perspective, especially in West Kalimantan, Indonesia, culture is a process coming from the ancient people who have known the form of animism and dynamism before the arrival of Hinduism, Buddhism and Islam. Animistic adherents believe that every object on earth has a soul and spirit that should be respected so that they do not disturb humans, and they are even helpful. Respecting the spirits of ancestors was done through ceremonies such as giving offerings. In dynamism belief system, all big objects such as big tree, big rock or mountain are believed to have magical power, so they need to be respected and guarded. ${ }^{12}$

Tradition of tolak bala is a local culture in Dabong village. The process of emerging tradition of tolak bala is because of feeling of fear which is later disappeared by giving offerings to certain places. Basically, tolak bala is an effort of Dabong society to gain protection from their Lord. In doing rituals they opened it with reciting basmalah and then filled with prayers and they closed it with saying hamdalah. From the explanation above, it is clear that Islam has relation with tradition which is part of culture, viewed from a historical perspective either externally or internally.

\section{Islam and Tradition in Indonesia Context}

Relation between Islam and tradition are often debated and claimed that may cause conflict. Basically, it is not problematic issue. It even contains a value of tolerance that can strengthen the relationship and brotherhood among Indonesian people. Geertz said that there are some factors which can solve the conflict, namely having the same feeling of one culture; religious style is not reflected directly in social forms, tolerance, and the existence of pluralistic social integration mechanisms. ${ }^{13}$

The meaning of diversity itself is "Although it's different but we are still one," it means that although we have different ethnicities, races and cultures, we can still unite with a culture that is interpreted as the power of spirituality, without spirituality people will get difficulty to accept and understand the differences. It can create peaceful condition in life. The values existing in relation between Islam and tradition is a local wisdom that can encourage national unity. Moral and value system of local system usually encourages intensive social interaction, feeling of togetherness, cooperation and peace. ${ }^{14}$

\footnotetext{
${ }^{11}$ Prof. H.A.R. Gibbb is the one who is not influenced by religious fanatics, free from all feeling of ta'assub, scientist's confession based on research he conducted.

${ }^{12}$ Taken from internet (Power Point) Eli Priyatna Laidan, 2015. Chapter 5 interaction among local culture, hunduism and Islam in Indonesia

13 Clifford GeertzAbangan, Santri, Priyayidalam Masyarakat Jawa, translated by Aswab Mahasin., (Bandung: Dunia Pustaka Jaya, 1981), p. 475-477

14 Al Rasyidin, et al., Harmonisasi Agama dan Budaya di Indonesia (2), (Jakarta:Balai Penelitian dan Pengembangan Agama Jakarta, 2009), p. 217
} 
The tradition which is still preserved its purity and developed in a country in which the majority is Muslim, often causes conflict. Therefore, the big problem in Indonesia can be solved through learning from relation between Islam and tradition. Based on the result of research conducted in Dabong village, when Islam is dealing with tradition, it is related one another. We have religion, and we also have to preserve local culture. Besides, it can show the existence of Indonesia's local culture.

On the other hand, Hocker and Wilmot studied about the concept of this relation by using psychological framework, the findings showed that there are five patterns of relation, namely: competition, collaboration, avoidance, accommodation and compromy.

\section{Hocker And Wilmot's Pattern}

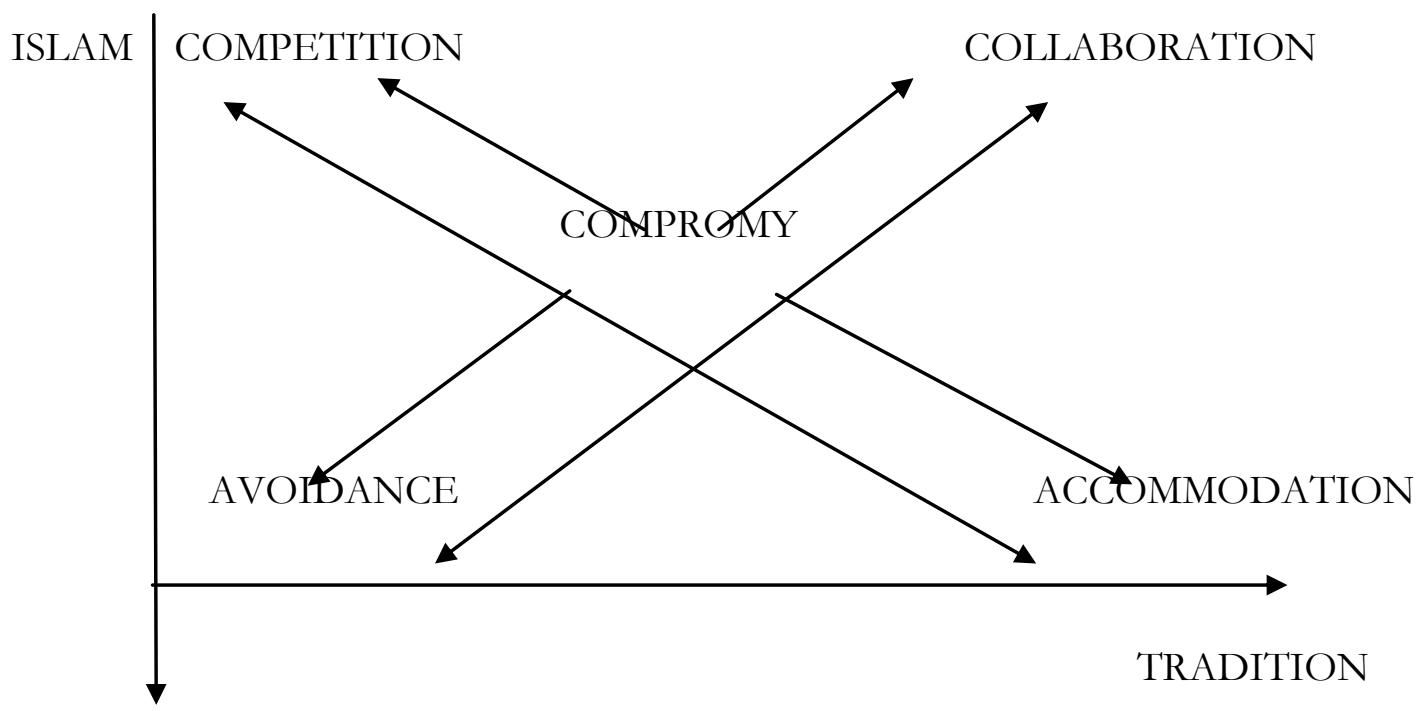

Figure 1: Cartography of relation between Islam and tradition is using proble solving pattern by Hocker and Wilmot. ${ }^{15}$

According to Deaux, Dane and Wrightsman (1993) competition is the activity of achieving goal by defeating other people or group. Individual or group choose to work together or compete depending on the reward structure in a situation. While according to Hocker \& Wilmot, competition is characterized by aggressive and non-cooperative behavior. This relation indicates that it prioritizes personal interest, and sacrifices the interest of others. Expression of relation in the form of courage opens direct confrontation and insists to win it without trying to adjust to the will and interest of others. This has a negative character because it can compete without having to harm other people. The relation between Islam and tradition in term of competition exists in tradition of tolak bala. Actually, the tradition of tolak bala and Islam competes in ritual of feeding the sea and village. Islam is not included in ritual, and the ritual itslef is not included in Islam. Likewise

${ }^{15}$ William Hocker \& Joyce Hocker, Interpersonal Conflict, (Colombus: Mc Graw-Hill Higher Education, 2013), p. 32 
sacred object, although sacred object has been eliminated, the tradition competed with Islam. However, the competition between Islam and tradition in Dabong Village did not cause a problem. Viewed from educational perspective, this phenomenon occurs because of lack of religious and cultural education. This phenomenon may lead to competition to defend Islam or tradition from the fanatics, whether fanatical on Islam or tradition.

According to Gillin Accommodation is an understanding used by sociologists to describe a process of social relation which means the understanding of adaptation needed by biologists to show a process in which living things adapt themselves to the surrounding environment. According to Hocker \& Wilmot, relation of accommodation is characterized by non-assertive relation but cooperative in the form of ignoring the interest for the sake of others' interest. From the explanation above, it can be understood that accommodation here means an individual process or process among humans who have opposition, then they try to adjust to each other in overcoming the problems. From the results of research, accommodation belongs to the type of relation between tradition of tolak bala and islam. Some people feel like they are contrary to the tradition of tolak bala in which they find deviated ritual elements, and some still believe in the ritual even though they have the same belief about religion that believes in the existence of one god, namely Allah SWT. This phenomenon creates relation, namely adjustment accommodation by sharing the belief, tradition and religion with others without any trouble.

According to Indonesian dictionary avoiding means staying away. In other words, someone or a group of people will stay away fom a culture if it deviates. The most important thing is how a person views the culture. That is why education is very important so that people know the right path, whether it is allowed or prohibited. According to Hocker \& Wilmot relation of avoidance is characterized by non-assertive and passive behaviors. A person doesn't not demand either for personal interest or others', they tend to remain silent, refuse to get involved in open problems; they even try to stay away from the possibility of face to face activity. In this case the tradition avoided by Dabong society was sacred object, which was regarded as a deviate tradition that should be avoided. However, the tradition of tolak bala cannot be claimed as syirik or deviate activity, because it is only a means of worship, for example tolak bala tradition is conducted with the aim to save the village which is addressed to Allah through the prayer and after that it continued with eating party. Tolak bala is considered syirik because they give the sea and forest food. This is absolutely not right because it is categorized as syirik. Syirik is big sin and Allah hates it so much. Islam doesn't teach us to do syirik.

According to Hocker \& Wilmot relation of collaboration needs high assertiveness accompanied with high involvement in interests of others. Both parties who are creatively related cooperate to find new solutions to reach the optimal goals together. The results of field survey showed that relation of collaboration was found in Barzanji tradition of Dabong community, which is closely related to Islam and tradition, so it created relation of collaboration to establish Islamic tradition namely Barzanji. According to Dr. Hariansyah Barzanji, it is an ordinary word that is sung. It is then coloured with Islam. From the 
opinion above, it can be concluded that a tradition may be able to relate to Islam which created collaboration. The collaboration of Barzanji tradition is a song from words which is then coloured with Islam and then replacing the words with shalawat for the Prophet Muhammad (p.b.u.h).

According to Indonesian dictionary, a compromy is a deal made by two parties who have dispute to solve it by finding the way out together. It means that compromy is an effort or make a deal between two people who have different opinion through communication. Compromy is done to solve the problem by making a new agreement. On the other hand, Lance Armstrong, it's not about the bike (2000) 2001 in Merriam Webster Dictionary said, you don't make deals that compromise yourself or your team, of course, but you help other riders you can, so they might return the favour. Meanwhile Hocker \& Wilmot stated relation of compromy is a relation existing in the middle of assertive and cooperative behaviour. This method is carried out when there is a disagreement regarding a matter, so both parties compromise each other and try to find a solution that satisfies one another. Therefore, compromy is the most effective way to overcome the problems. We can hold an approach through compromy not only to solve problems but also to settle down those who have a problem. Such phenomenon occurs in the process of sacred tradition, where a person strongly believed in sacred. On the other hand, Islam which has become their belief is considered only as a religion without having a relation with their tradition. However, with a long compromy process, finally Dabong society knew the thing which is forbidden and permitted in Islam, so a new agreement emerged to eliminate the tradition because it is contrary to Islam.

Based on the theories and explanations above, it can be concluded that Islam and tradition have broad meaning, spiritual and physical needs can unite those who have dispute. So, it has a strong point to interlace various relations in both internal and external context. If analyzed from its internal context, Islam and tradition have relation in their own objects. While the external context, when Islam is faced with tradition or vice versa, it will create several relations in a very wide range. These relations can be competition, accommodation, avoidance, collaboration and compromy as conceptualized by Hocker and Wilmot. However, relation between Islam and tradition in external contexts can produce religious, cultural, social, political and economic values.

\section{Islam and Tradition in Local Context (Dabong)}

Along with the strong local tradition that developed in a Muslim-majority country, of course there are many disputes among people in Indonesia, especially local people. The dispute is related with the relation between tradition and Islam, either compatible or incompatible. It is even contrary to Islam.

Based on the explanation above, Islam and tradition are two contrary poles, however, in practice there are values that cannot be separated. On the other hand, Islam and tradition are inseparable but can be distinguished. Tradition (Culture) can be an 
expression of religious life. While religion is absolute, it applies to every space and time; culture is relative, limited by space and time. ${ }^{16}$

For example, the tradition of tolak bala in Dabong village. Cultural behaviour is framed by the belief in God such as feeding the sea and village and then sends prayer which is opened with saying basmalah and is closed with saying bamdalah. These efforts are carried out to gain protection from their god.

The continuation of reconstruction of ritual practice is to give homage to God. This phenomenon is visible. Islam when faced with people who have different cultures and traditions is flexible. Religion and tradition have related each other because both have values and symbols.

Religion is a symbol that indicates the value of obedience to God. Culture also contains value and symbol so that humans can live among others. Religion requires symbols and religious culture. But both are different. Religion is something that is final, universal, eternal and absolute. Culture is relative and contemporary. Religion without culture can develop as a religion itself, but without a religious culture as collectivism, there will be no place for it. $^{17}$

The existence of relation between Islam and tradition occurs because Islam is religion of rahmatan lil'alamin for the universe, humans, animals, plants and spirit. Islam is an absolute religion yet flexible. So, it is easy to accept a different culture as long as it does not deviate from qur'an and sunnah.

The questions about being compatible or incompatible are clearly answered, and the assumption of debate between Islam and tradition. Basically, both are not problematic as long as in line with quran and sunnah.

\section{The Value of Nation's Connecter in Relation Between Islam and Tradition of Tolak Bala}

There are so many values produced from relation of Islam and tradition. It can be known from the research findings in Dabong village. The value of worship, for example, is seen when Islam is faced with tradition of tolak bala, namely, the existence of charity of giving food to each other, such as ketupat, cakes and etc. This tradition can strengthen the relationship among others. It is based on the teachings of Islam.

The celebration of tolak bala tradition can also lead to the context of tourism that finally will move the economy. This is in line with the response of religious figure who respond to tabot tradition which is precisely understood in the context of tourism and

\footnotetext{
${ }^{16}$ Nurcholish Madjid, Islam Agama Kemanusiaan, Membangun Tradisi dan Visi Baru Islam Indonesia, (Jakarta: Paramadina, 2003), p. 36

${ }^{17}$ Darori Amin (ed)., Islam dan Kebudayaan Jawa, (Yogyakarta: Gama Media, 2000), p. 11
} 
moves economy sector in province of Bengkulu. ${ }^{18}$ The cultural values gained from this relationship are characterized by behaviour, attitudes and customs of society, which are practiced in life. The understanding of tolak bala is one forms of local culture whose process is full of historical content in developing Islam. By having a unique cultural form, the procession and celebration of tolak bala can attract tourists.

The practice of existing tradition will also increase the cultures in Indonesia. It shows the existence of Indonesia which is not only rich in nature, islands, humans, but also rich in culture. If we see this relation, it also produces social value, when a tradition is practice like tolak bala, communication can strengthen the relationship among people. It causes interdependence in life, and they need each other and add wisdom, it is also Islamic teachings.

From the explanations above, it is clear that all values described above are the values of nation connecter, a value that functions to strengthen the relationship and unity, and creates local wisdom. These values are the examples for the big problem in Indonesia now. Some major problems happening in Indonesia now are inter-faith conflict, ethnicity and race, crime, corruption and even murder. All these problems occur because of lack of solidarity, injustice that may lead to criminal act.

Thus, relation between Islam and tradition is relevant to describe the condition of nation now. The Indonesia and even the world can learn from this tradition practice in Dabong. Two different sides which are always in harmony although the position is different yet Islam and tradition are related each other. When the relationship occurs, it creates Islamic values that can be a nation connecter.

\section{CONCLUSION}

The big problem in Indonesia can be overcome by learning from the relation between Islam and tradition which can strengthen relation among humans. The background is from a terminology that has no solution at all, but can create relations. The relation in this case means the relation may lead to harmony, peace and respect. Humans need religion and culture, meaning that fanatics about something may not be judged as hostility that leads to crime. Difference is something normal and it should not be a problem. Islam is a source of culture and rules that always lead to goodness in practicing the culture. The occurrence of relation between Islam and tradition is because Islam is the religion of rabmatan lil'alamin for the universe, humans, animals, plants and spirit. Islam is absolute religion yet flexible, so it is easy to accept a different culture as long as it doesn't not deviate from the rules contained in quran and sunnah. Additionally, there are also value and symbol between the two. Religion and culture cannot be separated but can be distinguished. Therefore, Islam is acceptable when humans have a strong tradition, because Islam succeeds in showing its existence in coloring a tradition. So Islam is called as religion of rahmatan lil'alamin. The

\footnotetext{
${ }^{18}$ Rohimin, et al., Harmonisasi Agama dan Budaya di Indonesia (2), (Jakarta : Balai Penelitian dan Pengembangan Agama Jakarta, 2009), p. 17
} 
Millatīi, Journal of Islamic Studies and Humanities, Vol. 4, No. 1, Juni 2019: 87-98

relationship formed by Islam and tradition also create many values, including religious, economic, political, cultural and social values. Relation between Islam and tradition also contain disparity values that can strengthen the relationship among humans in Indonesia. This can encourage and build a better future for Indonesia. However, the implementation of feeding the sea and village must be eliminated because it deviates from Islamic teaching. The duty of Dabong society is to remind each other of their Muslim fellows, and the tradition of tolak bala should be preserved because it is rich of values.

\section{REFERENCES}

Darori Amin (ed)., 2000. Islam dan Kebudayaan Jawa. Yogyakarta: Gama Media.

Geertz, Clifford. 1981. Abangan, Santri, Priyayidalam Masyarakat Jawa, terjemahan Aswab Mahasin. Bandung: Dunia Pustaka Jaya.

Hermansyah, dkk. 2007. Dayak Islam di Kalimantan Barat. Pontianak : STAIN Pontianak Press (Anggota IKAPI).

Ibrahim, 2015. Metodologi Penelitian Kualitatif. Bandung : ALFABETA,cv

Mahmoud M. Ayoub, 2004. ISLAM antara keyakinan dan praktik Ritual. Yogyakarta : AK GROUP

M. Natsir, 1988. Kebudayaan Islam dalam Perspektif Sejarah. Bandung : PT Karya Nusantara.

Nurcholish Madjid,2003. Islam Agama Kemanusiaan, Membangun Tradisi dan Visi Baru Islam Indonesia. Jakarta: Paramadina.

Rohimin, dkk. 2009. Harmonisasi Agama dan Budaya di Indonesia (2). Jakarta : Balai Penelitian dan Pengembangan Agama Jakarta.

Rustam A, dkk. 2005. Islam dan Peradaban Global. Pontianak : STAIN Pontianak Press (Anggota IKAPI dan AKADEMIA P3M).

Saiful A.M dan Yuda S, 2015. Teori Kebudayaan Interaksi lokal dengan Wisata Regionaldan Global. Medan: Penerbit Perdana Mitra Handalan. 